\title{
A Study of the Use of Picture Books by Preschool Educators in Outlying Islands of Taiwan
}

\author{
Ching-Yuan $\mathrm{Hsiao}^{1} \&$ Yang-Mei Chang ${ }^{2}$ \\ ${ }^{1}$ Department of Early Childhood Education, National University of Tainan, Tainan, Taiwan \\ ${ }^{2}$ Jhuo Huan Elementary School, Kinmen County, Taiwan \\ Correspondence: Ching-Yuan Hsiao, Department of Early Childhood Education, National University of Tainan. \\ Address: 33, Sec. 2, Shu-Lin St., Tainan 700, Taiwan. Tel: 886-929-040-353. E-mail: cyh111@mail.nutn.edu.tw
}

Received: June 1, 2015 Accepted: July 15, 2015 Online Published: December 28, 2015

doi:10.5539/ies.v9n1p1 URL: http://dx.doi.org/10.5539/ies.v9n1p1

\begin{abstract}
The objectives of the study were to investigate the current status of applying picture books when teaching children and to also compare the differences in picture book teaching between teachers with different background variables and who are from Taiwan's outlying islands. The researcher distributed 179 questionnaires, and after eliminating invalid questionnaires, 177 valid questionnaires were obtained, achieving a questionnaire efficiency of $98.88 \%$. The quantitative data were analyzed by a t-test, ANOVA, Pearson Product Moment Correlation and Multiple Regression. The results were: 1 . The overall status for picture book selection by early childhood educators was considered moderate to high. 2. The primary considerations for picture book selection were 'theme' and 'adopting a child's viewpoint'. 3. The overall status for the application of picture book teaching strategies among early childhood educators was considered moderate to high. 4 . The application of picture book teaching strategies was centered on 'strategies for the promotion of thinking and activities' and 'developing diverse abilities in children'. 5. There is a positive correlation and predictive power between selecting and using picture books by preschool educators.
\end{abstract}

Keywords: using picture books, preschool educators, outlying islands of Taiwan

\section{Research Background}

The cultivation of interests and reading skills has become a trend in the contemporary world. Taiwan's former Minister of Education, Wu (2010), stated, 'reading is the soul of education.' To elevate the quality of national education, culture and creativity, and to increase competitiveness on an international scale, a sound foundation and interest in reading are critical and should be developed at a young age. In 2001, the Ministry of Education launched a number of reading strategies and policies. In 2002, 334 recommended children's books were selected by MOE to public and private preschools around Taiwan in anticipation that teachers would employ picture book teaching to guide and encourage children to read at a young age, and develop the habit of reading (Wu, 2005). As the primary material that introduces children to the world of reading, picture books are critical and can substantially influence a child's interest in reading. Selecting appropriate picture books and utilizing relevant teaching strategies are important aspects that teachers must consider in order to maximize the effectiveness of picture book teaching, thereby instilling and maintaining children's passion for learning (Lin, 2009; Lin, 2008; $\mathrm{Su}, 1998)$.

Picture book resources on the outlying islands of Taiwan are quite limited compared to those of Taiwan's urban regions. In view of this, teachers employed by preschools on outlying islands were recruited as the research subjects for this study. In addition, some preschool teachers informed research that some obstacles of implementing picture books' curricula and instructional practice in the preschool on outlying islands; and so the objective of the present study was to explore the status of and differences in picture book teaching in these areas. The results of the present study can be used as a reference for the future promotion of picture book reading and teaching.

\section{Literature Review}

2.1 Factors When Selecting Picture Books

A wide range of picture books is available on the market. The appearance, version, categories, content, and 
themes of picture books can be overwhelming for those adults who are responsible for selecting suitable picture books for children. Numerous scholars' views on picture book selection for teachers are summarized and presented as follows:

\section{1) Adopting a child's perspective}

The primary considerations for selecting picture books are the child's development and their needs (Chang and Zheng, 2004). An ideal picture book should have characteristics that appeal to children. Although picture books are specifically developed for children, children of different ages also experience different paces of development; thus, their cognitive abilities vary. Therefore, children's abilities should be considered when selecting picture books. Children's interests and life experiences should also be considered when selecting picture books, with the focus on facilitating a child to enjoy reading and to resonate with what they have read.

2) Style and material

Appearance and style are crucial and determine whether a book can attract readers. The style of a picture book can be divided into five aspects: page layout, font, colors, paper, and binding. Page layout includes the cover, end sheets, and title pages. The cover is a crucial aspect because it contributes to the observer's first impression. The cover, end sheets, and title pages must be arranged coherently to highlight the content (Lin, 2009; Hong, 1994). The arrangement of the layout, illustrations, text, and chapters should be consistent. For example, the font size and line spacing should be appropriate so as to prevent eye fatigue from damaging children's vision (Hong, 1994).

\section{3) Figures and content}

Based on suggestions by numerous professionals and scholars, the illustrations and text in picture books embody both the practical and intangible; they are each equipped with unique characteristics, yet can be integrated and interactively used to highlight and convey the content (Lin, 2010; Lewis, 2001). The content of a picture book should be concise, easy to understand, equipped with a sensible plot, and contain positive values. Most of all, picture books must appeal to children and resonate with their lives, thereby triggering their interest and leading them to understand the meaning of the story and gain inspiration.

\section{4) Awards or endorsements}

When selecting picture books, teachers should consider picture books that have been awarded domestic or international prizes. Books recommended by non-commercial early childhood education websites can also be referenced. Picture books endorsed by these sources have gained the recognition of professionals and the public. When selecting the best picture books, awards and endorsements should be considered in conjunction with content and illustration (Lin, 2004; Chen, 2003; Ning, 2004).

\subsection{Applying Picture Books to Teaching}

Picture book teaching strategies involve the teacher including picture books in their teaching activities, considering the children's learning interests and needs, and employing appropriate teaching paths and methods to fulfill the learning objectives. The arguments and research proposed by numerous famous scholars in the field of picture books are summarized, and picture book teaching strategies divided into five categories:

1) Illustration appreciation guidance

A study entitled Teaching Appreciation of the Illustrations in Children's Reading (Lin, 2013) proposed that the communication of imagery should be emphasized when teaching the appreciation of illustrations. Illustrations enable the author and reader to intercommunicate spiritual imagery through vision. The reader deconstructs, analyzes, and reproduces the imagery of the illustrations and texts. Three principles should be considered when guiding children to appreciate illustrations: 1 . Allow children to actively participate in the appreciation by starting with the book selection; 2. Guide children to appreciate the illustrations from different viewpoints so as to inspire their creative thinking; 3 . Be attentive to individual differences during any illustration appreciation activities. Six strategies can be used: (a) storytelling through illustrations, (b) illustration and text comparisons, (c) plot analysis, (d) climax analysis, (e) outcome prediction, and (f) speech/song performance

2) Reading aloud

Three approaches can be used when reading aloud. The first method involves the teacher explaining the meaning of the vocabulary and terms whilst reading the story aloud. The second method purely focuses on the teacher reading the story. The third method is focused on the children, who either read the story solo or with a group. The process of reading aloud begins with stimulation of the children's motivation and interest in listening to stories and guiding them to become absorbed in the plot. Subsequently, a suitable reading speed is integrated 
with facial expressions and body language, and changes in intonation are used to bring the characters to life. Exaggerated expressions and movements enhance reading effectiveness. After the activity is completed, children should be allowed to discuss the story content and express their thoughts. Finally, the children can be provided with diverse extended activities to examine their level of understanding of the story (Chen, 2003).

3) Class and group shared activities

For shared reading activities in class, all children are provided with the same book and read simultaneously. With the teacher's guidance, the children can appreciate the illustrations and texts, read aloud, share their thoughts, discuss the story from their perspectives, brainstorm, and participate in extended activities (Lin, 2008). The objective of shared reading in class is to gather a group of people together to share and interact. Shared reading spurs different learning perspectives and triggers reading motivation (Lin, 2000).

\section{4) Applying e-picture books}

With the advancements in multimedia technology, teachers have utilized the convenience and vividness of multimedia tools and combined electronic materials with their teaching. E-picture books have now become a key tool for teaching activities ( $\mathrm{Li}, 2000)$. E-picture books combine children's literature, language, and illustrations with special effects, such as music and animation, thereby simultaneously stimulating their vision and hearing. Subsequently, their learning motivation and levels of understanding are increased. Thus, e-picture books are an optimal choice for teaching children (Mayer, 2006).

\section{5) Creating reading scenarios}

The classroom environment can affect student-teacher interactions, learning, thinking, and life. Ideal scenarios can increase teaching quality, whereas adverse scenarios will cause a decline in learning effectiveness (Roskos \& Neuman, 2011). Morroe (1992) attested that establishing a suitable reading corner in the classroom prompts children to treat reading as an important daily routine. Teachers can collect picture books and display them. Furthermore, lighting, cleanliness, routes, and displays should be sufficient and arranged according to the children's needs.

\subsection{Integrating Picture Books into Course and Activity Design}

The following steps should be considered when incorporating picture books into course design:

\section{1) Teacher's preparation}

Prior to picture book teaching, a comfortable area should be selected within the teaching environment and even decorated based on the theme of the picture book, thus enabling children to focus on the story while feeling at ease (Lin, 2008; Lin, 2004). When selecting picture books, children's experience, abilities, and interests must be considered. Teachers should be familiar with the picture book's topic, author, and content. Teachers should also contemplate what experience the picture book will give to the children and what teaching strategies to employ. Additionally, teachers can anticipate what questions to ask the children during discussions, what responses to expect, and what approach to adopt for guiding the children to formulate responses.

\section{2) During teaching activities}

First, children's motivation for reading picture books must be triggered. Teachers can discuss the illustrated cover and the name of the picture book with the children, and facilitate them to infer the story content (Huang, 1993). Additionally, the picture book should be presented in a way that all children can clearly see the illustrations. A suitable distance should be employed, or each child should first read the picture book themselves. The children's reactions must be monitored during the process of storytelling or reading aloud. To make the story more vivid, teachers can create an atmosphere for the story and should mimic the tones, expressions, and movements of the characters, events, and objects in the story. Furthermore, audiovisual equipment can be used in conjunction with the picture book to attract the children's attention and enable them to become invested in the plot (Ku, 2010; Lin, 2008).

\section{3) Extended activities following teaching sessions}

Through extended activities, children can become familiarized with the story content. Extended activities also facilitate children to contemplate their thoughts and express their emotions after reading. Extended activities for picture book teaching are abundant and diverse, and include independent, group, or class creative activities. The majority of extended activities are practical applications that involve a combination of art, music, dance, and drama (Hsiao, 2010). Regarding dynamic extended activities, Lin (2008) suggested off-campus activities, such as cooking, playing in parks, and visiting markets. Coupled with practical experiences, reading will enhance children's learning experiences. Making reading a game is also a good example of edutainment. 


\section{Research Objectives}

Based on the research background, motivation, and literature review, the objectives of the present study are centered on the following aspects:

1) The status of applying picture books when teaching children.

2) Comparing the differences in picture book teaching between teachers with different background variables.

3) Analysis of the relationship between teachers' selection of picture books and the application of picture book teaching strategies.

4) Analysis of the predictability of teachers' selection of picture books and the application of picture book teaching strategies.

\section{Methodology}

The objective of the present study was to elucidate the status of the application of picture book teaching for preschool educators residing and working in the outlying islands of Taiwan. The 'current status of picture book teaching by preschool educators in outlying islands questionnaire' was distributed, and the results were used to explore the differences, correlations, and predictability of picture book teaching application among teachers with different backgrounds.

\subsection{Research Subjects}

Personnel from public and private preschools on outlying islands (including Great Kinmen and Lesser Kinmen) in Taiwan were employed as the research subjects. Subjects included teachers, educare-givers, and educare-assistants from public and private preschools. Demographic data were sourced from the 2013 school year's first semester announcements from the outlying islands' government education offices. A total of 160 public and 19 private preschool teachers were the subjects. The researcher distributed 179 questionnaires, and after eliminating two invalid questionnaires, 177 questionnaires remained, achieving a questionnaire efficiency of $98.88 \%$.

\subsection{Research Tools}

The 'status of picture book teaching for outlying island preschool educators' questionnaire' was used as a research tool. The questionnaire was comprised of four sections: (a) personal information, (b) teachers' picture book consumption habits, (c) scale for teachers' picture book selection, and (d) scale for teachers' application of picture book teaching strategies. The results of questionnaire survey were compiled and quantified, thereby strengthening the research tools. The questionnaire underwent expert validity testing before being distributed. Additionally, the data processing used the following methods: The retrieved questionnaires were encoded and data exported to a computer. Subsequently, SPSS 20.0 software was used to conduct statistical analysis with the level of significance set at $\mathrm{p}<.05$. Descriptive analysis was employed to examine the subjects' background information. An independent sample t-test and analysis of variance (ANOVA) were applied to determine whether a significant difference existed between the subjects' background variables and their picture book selection and application. Pearson Product Moment Correlation (PPMC) and regression analysis were used to explore the predictability and correlation between the subjects' picture book selection and application.

\section{Finding and Discussion}

\subsection{Analyzing Picture Book Selection Differences among Preschool Teachers with Different Backgrounds}

The present study aims to discuss picture book selection differences among preschool teachers with different backgrounds. The background variables were treated as independent variables while picture book selection was treated as the dependent variable. The presence of significant differences was tested using $t$ testing and ANOVA. If the variance $\mathrm{F}>.05$ (thus reaching significance), the Scheffé method was then employed for multiple testing, thereby elucidating any picture book selection differences among teachers with different backgrounds.

\subsubsection{Analyzing Picture Book Selection Differences among Preschool Teachers with Different Years of Service}

Years of service was treated as the independent variable and categorized as $<5$ years, 6-10 years, 11-15 years, 16-20 years, and $>21$ years. Picture book selection was treated as the dependent variable. Descriptive analysis and ANOVA were conducted to understand the picture book selection differences among preschool teachers with different years of service. The results are presented as follows: 
Table 1. Summary of the descriptive analysis and ANOVA results for picture book selection differences among preschool teachers with different years of service $(n=177)$

\begin{tabular}{|c|c|c|c|c|c|c|c|}
\hline Subscale & $\begin{array}{l}\text { Years of } \\
\text { Service }\end{array}$ & $\begin{array}{l}\text { No. of } \\
\text { People }\end{array}$ & Mean & $\begin{array}{l}\text { Standard } \\
\text { Deviation }\end{array}$ & $\begin{array}{c}\mathrm{F} \\
\text { Value }\end{array}$ & Significance & $\begin{array}{l}\text { Post Hoc } \\
\text { Comparison }\end{array}$ \\
\hline \multirow{6}{*}{ Content and Style } & 1. $<5$ years & 60 & 3.15 & 0.67 & \multirow{6}{*}{0.371} & \multirow{6}{*}{0.829} & \multirow{6}{*}{$\mathrm{N}$} \\
\hline & 2. 6-10 years & 63 & 3.17 & 0.81 & & & \\
\hline & $3.11-15$ years & 20 & 3.24 & 0.78 & & & \\
\hline & 4.16-20 years & 14 & 3.41 & 0.79 & & & \\
\hline & 5. $>21$ years & 20 & 3.21 & 0.79 & & & \\
\hline & Total & 177 & 3.19 & 0.75 & & & \\
\hline \multirow{6}{*}{ Theme } & 1. $<5$ years & 60 & 4.22 & 0.57 & \multirow{6}{*}{2.648} & \multirow{6}{*}{$0.035 *$} & \multirow{6}{*}{$2>3$} \\
\hline & 2.6-10 years & 63 & 4.37 & 0.55 & & & \\
\hline & $3.11-15$ years & 20 & 3.95 & 0.69 & & & \\
\hline & 4.16-20 years & 14 & 4.50 & 0.76 & & & \\
\hline & 5. $>21$ years & 20 & 4.38 & 0.63 & & & \\
\hline & Total & 177 & 4.28 & 0.61 & & & \\
\hline \multirow{6}{*}{$\begin{array}{l}\text { Diverse Characteristics and } \\
\text { Cultural Implications }\end{array}$} & 1. $<5$ years & 60 & 3.23 & 0.73 & \multirow{6}{*}{3.168} & \multirow{6}{*}{$0.015 *$} & \multirow{6}{*}{$2>1$} \\
\hline & 2.6-10 years & 63 & 3.64 & 0.77 & & & \\
\hline & $3.11-15$ years & 20 & 3.48 & 0.85 & & & \\
\hline & $4.16-20$ years & 14 & 3.75 & 0.96 & & & \\
\hline & 5. $>21$ years & 20 & 3.75 & 0.72 & & & \\
\hline & Total & 177 & 3.51 & 0.80 & & & \\
\hline \multirow{6}{*}{ Adopting a child's viewpoint } & 1. $<5$ years & 60 & 4.35 & 0.47 & \multirow{6}{*}{4.683} & \multirow{6}{*}{$0.001 * *$} & \multirow{6}{*}{$2>1$} \\
\hline & $2.6-10$ years & 63 & 4.60 & 0.45 & & & \\
\hline & $3.11-15$ years & 20 & 4.29 & 0.56 & & & \\
\hline & 4.16-20 years & 14 & 4.48 & 0.72 & & & \\
\hline & 5. $>21$ years & 20 & 4.78 & 0.30 & & & \\
\hline & Total & 177 & 4.49 & 0.50 & & & \\
\hline \multirow{6}{*}{ Other } & 1. $<5$ years & 60 & 2.79 & 0.76 & \multirow{6}{*}{1.542} & \multirow{6}{*}{0.192} & \multirow{6}{*}{$\mathrm{N}$} \\
\hline & $2.6-10$ years & 63 & 3.10 & 0.83 & & & \\
\hline & $3.11-15$ years & 20 & 3.07 & 0.85 & & & \\
\hline & 4.16-20 years & 14 & 2.83 & 0.71 & & & \\
\hline & 5. $>21$ years & 20 & 2.78 & 0.63 & & & \\
\hline & Total & 177 & 2.93 & 0.78 & & & \\
\hline \multirow{6}{*}{$\begin{array}{l}\text { Total Scale for Picture Book } \\
\text { Selection }\end{array}$} & 1. $<5$ years & 60 & 3.55 & 0.41 & \multirow{6}{*}{2.713} & \multirow{6}{*}{$0.032 *$} & \multirow{6}{*}{$2>1$} \\
\hline & $2.6-10$ years & 63 & 3.78 & 0.45 & & & \\
\hline & 3.11-15years & 20 & 3.60 & 0.49 & & & \\
\hline & $4.16-20$ years & 14 & 3.80 & 0.48 & & & \\
\hline & 5. $>21$ years & 20 & 3.78 & 0.41 & & & \\
\hline & Total & 177 & 3.68 & 0.45 & & & \\
\hline
\end{tabular}

$* \mathrm{p}<.05, * * \mathrm{p}<.01$ 
Table 1 indicates the significant differences between teachers with different years of service in regards to the 'content and style', 'theme', 'diverse characteristics and cultural implications', 'adopting a child's viewpoint' and 'total scale for picture book selection'. The Scheffe's post hoc comparison results indicated that the 'theme' dimension was significantly higher for teachers in the 6-10 year group compared to those in the 11-15 year group. As for dimensions such as 'diverse characteristics and cultural implications' and 'adopting a child's viewpoint', teachers in the 6-10 year group exhibited significantly higher results than those in the $<5$ year group. These results suggest that years of service significantly influence overall picture book selection. No significant difference was observed between the dimensions of 'content and style' and 'other,' which implies that the years of service did not affect the subjects' choices in these two dimensions.

\subsection{Analyzing Differences in Picture Book Teaching Strategies among Preschool Teachers with Different Backgrounds}

\subsubsection{Analyzing Differences in Preschool Teachers' Teaching Models Used for Picture Book Teaching}

Teaching models were treated as independent variables and categorized into theme-based teaching approaches, learning area, unit teaching, and other teaching methods. The subjects' picture book teaching strategies were treated as dependent variables. Descriptive analysis and ANOVA were conducted to understand the differences in the teaching strategies employed by teachers using different teaching models. The results are presented as follows:

Table 2. Summary of the descriptive analysis and ANOVA results for differences in teaching strategies employed by teachers with different teaching models $(\mathrm{n}=177)$

\begin{tabular}{|c|c|c|c|c|c|c|c|}
\hline Subscale & Teaching models & $\begin{array}{l}\text { No. of } \\
\text { People }\end{array}$ & Mean & $\begin{array}{c}\text { Standard } \\
\text { Deviation }\end{array}$ & $\begin{array}{c}\mathrm{F} \\
\text { Value }\end{array}$ & Significance & $\begin{array}{l}\text { Post Hoc } \\
\text { Comparison }\end{array}$ \\
\hline \multirow{5}{*}{$\begin{array}{l}\text { Strategies for Developing Diverse } \\
\text { Abilities in Children }\end{array}$} & 1. Theme-based & 129 & 4.12 & 0.53 & \multirow{5}{*}{2.202} & \multirow{5}{*}{0.090} & \multirow{5}{*}{$\mathrm{N}$} \\
\hline & 2. Learning Area & 6 & 4.40 & 0.35 & & & \\
\hline & 3. Unit Teaching & 20 & 3.86 & 0.61 & & & \\
\hline & $\begin{array}{l}\text { 4. Other teaching } \\
\text { methods }\end{array}$ & 22 & 4.05 & 0.38 & & & \\
\hline & Total & 177 & 4.09 & 0.52 & & & \\
\hline \multirow{5}{*}{$\begin{array}{l}\text { Strategies for the Promotion of } \\
\text { Thinking and Activities }\end{array}$} & 1. Theme-based & 129 & 4.26 & 0.64 & \multirow{5}{*}{0.759} & \multirow{5}{*}{0.518} & \multirow{5}{*}{$\mathrm{N}$} \\
\hline & 2. Learning Area & 6 & 4.50 & 0.45 & & & \\
\hline & 3. Unit Teaching & 20 & 4.10 & 0.50 & & & \\
\hline & $\begin{array}{l}\text { 4. Other teaching } \\
\text { methods }\end{array}$ & 22 & 4.23 & 0.51 & & & \\
\hline & Total & 177 & 4.25 & 0.61 & & & \\
\hline \multirow{5}{*}{$\begin{array}{l}\text { Strategies for Using Electronic } \\
\text { Teaching Aids as Auxiliary Tools }\end{array}$} & 1. Theme-based & 129 & 3.58 & 0.78 & \multirow{5}{*}{2.016} & \multirow{5}{*}{0.114} & \multirow{5}{*}{$\mathrm{N}$} \\
\hline & 2. Learning Area & 6 & 3.33 & 0.41 & & & \\
\hline & 3. Unit Teaching & 20 & 3.15 & 0.83 & & & \\
\hline & $\begin{array}{l}\text { 4. Other teaching } \\
\text { methods }\end{array}$ & 22 & 3.64 & 0.79 & & & \\
\hline & Total & 177 & 3.53 & 0.78 & & & \\
\hline \multirow{5}{*}{$\begin{array}{l}\text { Strategies for Extending Picture } \\
\text { Book Courses }\end{array}$} & 1. Theme-based & 129 & 3.60 & 0.92 & \multirow{5}{*}{2.475} & \multirow{5}{*}{0.063} & \multirow{5}{*}{$\mathrm{N}$} \\
\hline & 2. Learning Area & 6 & 3.00 & 1.41 & & & \\
\hline & 3. Unit Teaching & 20 & 3.08 & 0.94 & & & \\
\hline & $\begin{array}{l}\text { 4. Other teaching } \\
\text { methods }\end{array}$ & 22 & 3.55 & 0.90 & & & \\
\hline & Total & 177 & 3.52 & 0.95 & & & \\
\hline
\end{tabular}




\begin{tabular}{|c|c|c|c|c|c|c|c|}
\hline \multirow{5}{*}{$\begin{array}{l}\text { Strategies for Parent-Child Shared } \\
\text { Reading }\end{array}$} & 1. Theme-based & 129 & 3.70 & 0.82 & \multirow{5}{*}{5.991} & \multirow{5}{*}{$0.001 * *$} & \multirow{5}{*}{$\begin{array}{l}1>3 \\
4>3\end{array}$} \\
\hline & 2. Learning Area & 6 & 2.92 & 0.74 & & & \\
\hline & 3. Unit Teaching & 20 & 2.96 & 0.87 & & & \\
\hline & $\begin{array}{l}\text { 4. Other teaching } \\
\text { methods }\end{array}$ & 22 & 3.69 & 0.86 & & & \\
\hline & Total & 177 & 3.59 & 0.86 & & & \\
\hline \multirow{5}{*}{$\begin{array}{l}\text { Strategies } \\
\text { Decoration }\end{array}$} & 1. Theme-based & 129 & 3.07 & 1.07 & \multirow{5}{*}{3.428} & \multirow{5}{*}{$0.018 *$} & \multirow{5}{*}{$1>3$} \\
\hline & 2. Learning Area & 6 & 3.67 & 0.88 & & & \\
\hline & 3. Unit Teaching & 20 & 2.38 & 1.10 & & & \\
\hline & $\begin{array}{l}\text { 4. Other teaching } \\
\text { methods }\end{array}$ & 22 & 3.20 & 1.11 & & & \\
\hline & Total & 177 & 3.03 & 1.10 & & & \\
\hline \multirow{5}{*}{$\begin{array}{l}\text { Total Scale for Applying Picture } \\
\text { Book Teaching Strategies }\end{array}$} & 1. Theme-based & 129 & 3.72 & 0.54 & \multirow{5}{*}{4.536} & \multirow{5}{*}{$0.004 * *$} & \multirow{5}{*}{$\begin{array}{l}1>3 \\
4>3\end{array}$} \\
\hline & 2. Learning Area & 6 & 3.64 & 0.27 & & & \\
\hline & 3. Unit Teaching & 20 & 3.25 & 0.56 & & & \\
\hline & $\begin{array}{l}\text { 4. Other teaching } \\
\text { methods }\end{array}$ & 22 & 3.73 & 0.52 & & & \\
\hline & Total & 177 & 3.67 & 0.55 & & & \\
\hline
\end{tabular}

$* \mathrm{p}<.05, * * \mathrm{p}<.01$.

The results indicated that subjects who selected 'other teaching methods' stated that they combined at least two of the three other teaching methods as teaching models. Data presented in Table 2 indicate that teachers who selected different teaching methods also exhibited a significant difference between the mean scores of 'strategies for parent-child shared reading', 'strategies for environment decoration', and 'total scale for applying picture book teaching strategies'. The Scheffe's post hoc test results showed that the scores for 'strategies for parent-child shared reading' and 'total scale for applying picture book teaching strategies' for subjects who combined a theme-based teaching approach with at least two teaching methods were significantly higher than that of teachers who adopted the unit teaching method. Teachers who applied a theme-based teaching approach exhibited a significantly higher score in the 'strategies for environment decoration' dimension compared to teachers who applied the unit teaching method. Overall, these results confirm that different teaching models exhibit a significant influence on picture book teaching strategies.

\subsection{Analysis on Preschool Teachers' Picture Book Selection and Teaching Strategy Application}

The present study attempted to explore the correlation between preschool teachers' picture book selection and teaching strategy application. PPMC was used to conduct statistical analysis and determine whether a significant difference was present. The details are presented in Table 3: 
Table 3. Summary of the correlation between various dimensions of the picture book selection scale and the picture book teaching strategy application scale

\begin{tabular}{|c|c|c|c|c|c|c|}
\hline Dimensionality & & $\begin{array}{l}\text { Content } \\
\text { and Style }\end{array}$ & Theme & $\begin{array}{c}\text { Diverse Characteristics and } \\
\text { Cultural Implications }\end{array}$ & $\begin{array}{c}\text { Adopting a child's } \\
\text { viewpoint }\end{array}$ & Other \\
\hline \multirow{2}{*}{$\begin{array}{l}\text { Strategies for Developing } \\
\text { Abilities in Children }\end{array}$} & $\begin{array}{l}\text { Correlation } \\
\text { Coefficient }\end{array}$ & 0.377 & 0.266 & 0.475 & 0.391 & 0.342 \\
\hline & Significance & $0.000 * \star$ & $\begin{array}{l}0.000 \\
* *\end{array}$ & $0.000 * *$ & $0.000 * *$ & $\begin{array}{l}0.000 \\
* *\end{array}$ \\
\hline \multirow{2}{*}{\multicolumn{2}{|c|}{$\begin{array}{l}\text { Strategies for the promotion of thinking Coefficient } \\
\text { and activities } \\
\text { Significance }\end{array}$}} & 0.309 & 0.125 & 0.293 & 0.350 & 0.240 \\
\hline & & $0.000 * *$ & 0.096 & $0.000 * *$ & $0.000 * *$ & $\begin{array}{l}0.000 \\
* *\end{array}$ \\
\hline \multirow{2}{*}{\multicolumn{2}{|c|}{$\begin{array}{lr}\text { Strategies for Using Electronic Teaching Coefficient } \\
\text { Aids as Auxiliary Tools } & \text { Significance }\end{array}$}} & 0.279 & 0.155 & 0.243 & 0.204 & 0.218 \\
\hline & & $0.000 * *$ & $\begin{array}{c}0.040 \\
*\end{array}$ & $0.001 * *$ & $0.007 * *$ & $\begin{array}{l}0.004 \\
* *\end{array}$ \\
\hline \multirow{2}{*}{$\begin{array}{l}\text { Strategies for Extending Picture Book } \\
\text { Courses }\end{array}$} & $\begin{array}{l}\text { Correlation } \\
\text { Coefficient }\end{array}$ & 0.256 & 0.080 & 0.274 & 0.075 & 0.246 \\
\hline & Significance & $0.001 * \star$ & 0.291 & $0.000 * \star$ & 0.319 & $\begin{array}{l}0.001 \\
* *\end{array}$ \\
\hline \multirow{2}{*}{$\begin{array}{l}\text { Strategies } \\
\text { Reading }\end{array}$} & $\begin{array}{l}\text { Correlation } \\
\text { Coefficient }\end{array}$ & 0.204 & 0.146 & 0.231 & 0.129 & 0.151 \\
\hline & Significance & $0.006 * *$ & 0.052 & $0.002 * \star$ & 0.086 & $\begin{array}{c}0.044 \\
*\end{array}$ \\
\hline \multirow{2}{*}{ Strategies for Environment Decoration } & $\begin{array}{l}\text { Correlation } \\
\text { Coefficient }\end{array}$ & 0.394 & 0.021 & 0.242 & 0.081 & 0.362 \\
\hline & Significance & $0.000 * *$ & 0.781 & $0.001 * \star$ & 0.284 & $\begin{array}{l}0.000 \\
* *\end{array}$ \\
\hline
\end{tabular}

$* \mathrm{p}<.05, * * \mathrm{p}<.01$.

The analysis results for the correlation between the various dimensions of the picture book selection scale and picture book teaching strategy application scale are detailed as follows:

1) A significant and positive correlation was observed between 'content and style' and all dimensions of the picture book teaching strategy application scale, with 'strategies for environment decoration' exhibiting the highest correlation at 0.394 . However, this correlation is relatively low in general terms.

2) A significant and positive correlation was observed between 'content and style' and the 'strategies for developing diverse abilities in children' and 'strategies for using electronic teaching aids as auxiliary tools' dimensions of the picture book teaching strategies application scale, with 'strategies for developing diverse abilities in children' exhibiting the highest correlation at 0.266 . However, this correlation is relatively low in general terms.

3) A significant and positive correlation was observed between 'diverse characteristics and cultural implications' and the various dimensions of the picture book teaching strategy application scale, with 'strategies for developing diverse abilities in children' exhibiting the highest correlation at 0.475 . This correlation is considered moderate in general terms.

4) A significant and positive correlation was observed between 'adopting a child's viewpoint' and the 'strategies for developing diverse abilities in children,' 'strategies for the promotion of thinking and activities,' and 'strategies for using electronic teaching aids as auxiliary tools' dimensions of the picture book teaching strategy application scale, with 'strategies for developing diverse abilities in children' exhibiting the highest correlation at 0.391 . However, this correlation is relatively low in general terms. 
5) A significant and positive correlation was observed between 'other' and all dimensions of the picture book teaching strategy application scale, with 'strategies for environment decoration' exhibiting the highest correlation at 0.362 . However, this correlation is relatively low in general terms.

\subsection{The Predictability of Preschool Teachers' Picture Book Selection in the Application of Picture Book Teaching} Strategy

Multiple regression analysis was conducted to determine whether teachers' picture book selection exhibits predictability in the application of picture book teaching strategy. The various dimensions of picture book selection were employed as the predictors, and the various dimensions of picture book teaching strategies were used as criterion variables. The details of the analysis are presented in Tables 4, 5, and 6:

Table 4. Summary of the multiple regression analysis results on the predictability of the subjects' picture book selection on overall application of picture book teaching strategy

\begin{tabular}{|c|c|c|c|c|}
\hline Predictor & $\begin{array}{l}\text { Multiple } \\
\text { Correlation } \\
\text { Coefficient(R) }\end{array}$ & $\begin{array}{l}\text { Standardized } \\
\text { Regression } \\
\text { Coefficient }(\beta)\end{array}$ & t Value & P Value \\
\hline Content and Style & 0.169 & 0.232 & 3.082 & $0.002 *$ \\
\hline Theme & -0.041 & -0.045 & -0.620 & 0.536 \\
\hline $\begin{array}{l}\text { Diverse Characteristics and Cultural } \\
\text { Implications }\end{array}$ & 0.158 & 0.229 & 3.107 & $0.002 * *$ \\
\hline Adopting a child's viewpoint & 0.173 & 0.158 & 2.219 & $0.028^{*}$ \\
\hline Other & 0.155 & 0.221 & 3.160 & $0.002 * *$ \\
\hline Correlation Coefficient R 0.559 & \multicolumn{4}{|c|}{ Coefficient of Determination R2 0.313} \\
\hline
\end{tabular}

$* \mathrm{p}<.05, * * \mathrm{p}<.01$.

Table 4 indicates that, regarding the subjects' picture book selection, the variables of 'content and style', 'diverse characteristics and cultural implications', 'adopting a child's 'viewpoint' and 'other' exhibited a significant predictability on 'overall picture book teaching strategy application'. All four variables exhibited a positive predictability. In other words, a higher score in these variables indicates a higher score for the overall application of picture book teaching strategy. 
Table 5. Summary of multiple regression analysis for the predictability of the subjects' picture book selection on 'strategies for developing diverse abilities in children', 'strategies for the promotion of thinking and activities', and 'strategies for using electronic teaching aids as auxiliary tools'

Teaching Strategies

\begin{tabular}{|c|c|c|c|c|c|c|c|c|c|}
\hline \multirow[b]{2}{*}{ Predictor } & \multicolumn{3}{|c|}{$\begin{array}{l}\text { Developing Diverse } \\
\text { Abilities in Children }\end{array}$} & \multicolumn{2}{|c|}{$\begin{array}{l}\text { Strategies for the } \\
\text { promotion of thinking } \\
\text { and activities }\end{array}$} & \multicolumn{4}{|c|}{$\begin{array}{l}\text { Strategies for Using Electronic } \\
\text { Teaching Aids as Auxiliary Tools }\end{array}$} \\
\hline & $\mathrm{R}$ & $\beta$ & $\mathrm{P}$ & $\mathrm{R}$ & $\beta$ & $\mathrm{P}$ & $\mathrm{R}$ & $\beta$ & $\mathrm{P}$ \\
\hline Content and Style & 0.077 & 0.110 & 0.128 & 0.124 & 0.153 & 0.057 & 0.163 & 0.088 & $0.047^{*}$ \\
\hline Theme & -0.002 & -0.002 & 0.979 & -0.109 & -0.109 & 0.163 & 0.024 & 0.106 & 0.823 \\
\hline $\begin{array}{l}\text { Diverse } \\
\text { Characteristics } \\
\text { and Cultural } \\
\text { Implications }\end{array}$ & 0.201 & 0.308 & $0.000 * *$ & 0.116 & 0.153 & 0.054 & 0.106 & 0.082 & 0.198 \\
\hline $\begin{array}{l}\text { Adopting a } \\
\text { child's viewpoint }\end{array}$ & 0.289 & 0.277 & $0.000 * *$ & 0.389 & 0.320 & $0.000 * *$ & 0.203 & 0.126 & 0.109 \\
\hline \multirow[t]{2}{*}{ Other } & 0.133 & 0.201 & $0.003 * *$ & 0.098 & 0.126 & 0.093 & 0.116 & 0.079 & 0.143 \\
\hline & \multicolumn{3}{|c|}{$\begin{array}{l}\text { Coefficient of } \\
\text { DeterminationR2 } 0.364\end{array}$} & \multicolumn{3}{|c|}{$\begin{array}{l}\text { Coefficient of } \\
\text { DeterminationR2 } 0.221\end{array}$} & \multicolumn{3}{|c|}{$\begin{array}{l}\text { Coefficient of } \\
\text { DeterminationR2 } 0.124\end{array}$} \\
\hline
\end{tabular}

$* \mathrm{p}<.05, * * \mathrm{p}<.01$.

Table 5 indicates three facts. First, regarding the subjects' picture book selection, the variables of 'diverse characteristics and cultural implications', 'adopting a child's 'viewpoint' and 'other' exhibited significant predictability regarding 'strategies for developing diverse abilities in children'. All three variables exhibited positive predictability. In other words, a higher score in these variables indicates a higher score for 'strategies for developing diverse abilities in children'. Second, the only variable that exhibited significant predictability regarding 'a strategy for the promotion of thinking and activities' was 'adopting a child's viewpoint'. This variable exhibited positive predictability. In other words, a higher score in this variable indicates a higher score for 'adopting a child's viewpoint'. Third, the only variable that exhibited significant predictability regarding 'strategies for using electronic teaching aids as auxiliary tools' was 'content and style'. This variable exhibited positive predictability. In other words, a higher score in this variable indicates a higher score for 'strategies for using electronic teaching aids as auxiliary tools'. 
Table 6. Summary of multiple regression analysis for the predictability of the subjects' picture book selection on 'strategies for extending picture book courses', 'strategies for parent-child shared reading', and 'strategies for environment decoration'

Teaching Strategies

\begin{tabular}{|c|c|c|c|c|c|c|c|c|c|}
\hline \multirow[b]{2}{*}{ Predictor } & \multicolumn{3}{|c|}{$\begin{array}{l}\text { Strategies for Extending } \\
\text { Picture Book Courses }\end{array}$} & \multicolumn{3}{|c|}{$\begin{array}{l}\text { Strategies for Parent-Child } \\
\text { Shared Reading }\end{array}$} & \multicolumn{3}{|c|}{$\begin{array}{l}\text { Strategies for Environment } \\
\text { Decoration }\end{array}$} \\
\hline & $\mathrm{R}$ & $\beta$ & $P$ & $\mathrm{R}$ & $\beta$ & $P$ & $\mathrm{R}$ & $\beta$ & $\mathrm{P}$ \\
\hline $\begin{array}{l}\text { Content and } \\
\text { Style }\end{array}$ & 0.146 & 0.116 & 0.176 & 0.109 & 0.095 & 0.277 & 0.396 & 0.272 & $0.001 * *$ \\
\hline Theme & -0.043 & -0.027 & 0.741 & 0.070 & 0.049 & 0.561 & -0.185 & -0.103 & 0.189 \\
\hline $\begin{array}{l}\text { Diverse } \\
\text { Characteristics } \\
\text { and Cultural } \\
\text { Implications }\end{array}$ & 0.234 & 0.196 & $0.020 *$ & 0.155 & 0.144 & $0.044^{*}$ & 0.135 & 0.098 & 0.216 \\
\hline $\begin{array}{l}\text { Adopting a } \\
\text { child's } \\
\text { viewpoint }\end{array}$ & 0.007 & 0.004 & 0.964 & 0.082 & 0.048 & 0.565 & 0.069 & 0.032 & 0.678 \\
\hline \multirow[t]{2}{*}{ Other } & 0.182 & 0.151 & 0.059 & 0.076 & 0.069 & 0.396 & 0.322 & 0.231 & $0.002 * *$ \\
\hline & \multicolumn{3}{|c|}{$\begin{array}{l}\text { Coefficient of } \\
\text { DeterminationR2 } 0.118\end{array}$} & \multicolumn{3}{|c|}{$\begin{array}{l}\text { Coefficient of } \\
\text { DeterminationR2 } 0.077\end{array}$} & \multicolumn{3}{|c|}{$\begin{array}{l}\text { Coefficient of } \\
\text { DeterminationR2 } 0.215\end{array}$} \\
\hline
\end{tabular}

Table 6 indicates three facts. First, regarding the subjects' picture book selection, the only variable that exhibited significant predictability regarding 'strategies for extending picture book courses' was 'diverse characteristics and cultural implications'. This variable exhibited positive predictability. In other words, a higher score in this variable indicates a higher score for 'strategies for extending picture book courses'. Second, the only variable that exhibited significant predictability regarding 'strategies for parent-child shared reading' was 'diverse characteristics and cultural implications'. This variable exhibited positive predictability. In other words, a higher score in this variable indicates a higher score for 'strategies for parent-child shared reading'. Third, regarding the subjects' picture book selection, the variables of 'content and style' and 'other' exhibited a significant predictability on 'strategies for environment decorating'. Both variables exhibited a positive predictability. In other words, a higher score in these variables indicates a higher score for 'content and style'.

\subsection{Comprehensive Analysis and Discussion}

5.5.1 Analysis on the Difference in Picture Book Selection for Preschool Teachers with Different Backgrounds

An independent sample t-test and ANOVA were employed for statistical analysis. The results are presented and further discussed in Table 7: 
Table 7. Summary of the analysis results for differences in picture book selection among teachers with different background variables

\begin{tabular}{|c|c|c|c|c|c|c|c|}
\hline $\begin{array}{l}\text { Background } \\
\text { Variable }\end{array}$ & Variable Attribute & $\begin{array}{l}\text { Content } \\
\text { and Style }\end{array}$ & Theme & $\begin{array}{l}\text { Diverse } \\
\text { Characteristics and } \\
\text { Cultural } \\
\text { Implications }\end{array}$ & $\begin{array}{l}\text { Adopting a } \\
\text { child's } \\
\text { viewpoint }\end{array}$ & Other & $\begin{array}{l}\text { Overall } \\
\text { Considerations for } \\
\text { Picture Book } \\
\text { Selection }\end{array}$ \\
\hline \multirow{3}{*}{ Job Title } & 1.Teacher & \multirow{3}{*}{$\mathrm{N}$} & \multirow{3}{*}{$\mathrm{N}$} & \multirow{3}{*}{$\mathrm{N}$} & \multirow{3}{*}{$\mathrm{N}$} & \multirow{3}{*}{$\mathrm{N}$} & \multirow{3}{*}{$\mathrm{N}$} \\
\hline & 2.Educare-giver & & & & & & \\
\hline & 3. Educare-Assistant & & & & & & \\
\hline \multirow{6}{*}{ Age } & 1. $<25$ & \multirow{6}{*}{$\mathrm{N}$} & \multirow{6}{*}{$\mathrm{N}$} & \multirow{6}{*}{$\mathrm{N}$} & \multirow{6}{*}{$\begin{array}{l}6>1 \\
6>4\end{array}$} & \multirow{6}{*}{$\mathrm{N}$} & \multirow{6}{*}{$\mathrm{N}$} \\
\hline & 2. $26-30$ & & & & & & \\
\hline & & & & & & & \\
\hline & 4. $36-40$ & & & & & & \\
\hline & 5. $41-45$ & & & & & & \\
\hline & 6. $>46$ & & & & & & \\
\hline \multirow{5}{*}{$\begin{array}{l}\text { Educational } \\
\text { Degree }\end{array}$} & 1. High school & \multirow{5}{*}{$\mathrm{N}$} & \multirow{5}{*}{$\mathrm{N}$} & \multirow{5}{*}{$\mathrm{N}$} & \multirow{5}{*}{$\mathrm{N}$} & \multirow{5}{*}{$\mathrm{N}$} & \multirow{5}{*}{$\mathrm{N}$} \\
\hline & 2. College & & & & & & \\
\hline & 3. University & & & & & & \\
\hline & 4. Graduate institute & & & & & & \\
\hline & 5. Non-related & & & & & & \\
\hline \multirow{5}{*}{$\begin{array}{l}\text { Years of } \\
\text { Teaching }\end{array}$} & 1. $<5$ years & \multirow{5}{*}{$\mathrm{N}$} & \multirow{5}{*}{$2>3$} & \multirow{5}{*}{$2>1$} & \multirow{5}{*}{$2>1$} & \multirow{5}{*}{$\mathrm{N}$} & \multirow{5}{*}{$2>1$} \\
\hline & 2.6-10years & & & & & & \\
\hline & 3.11-15years & & & & & & \\
\hline & 4.16-20years & & & & & & \\
\hline & 5. $>21$ years & & & & & & \\
\hline \multirow{5}{*}{ Class } & 1.Senior Class & \multirow{5}{*}{$\mathrm{N}$} & & & & & \\
\hline & 2.Middle Class & & & & & & \\
\hline & 3.Junior Class & & $\mathrm{N}$ & $\mathrm{N}$ & $\mathrm{N}$ & $\mathrm{N}$ & $\mathrm{N}$ \\
\hline & 4.Nursery & & & & & & \\
\hline & 5.Mixed-age class & & & & & & \\
\hline & $\begin{array}{l}\text { 1.Raised on outlying } \\
\text { islands }\end{array}$ & & & & & & \\
\hline Upbringing & $\begin{array}{l}\text { 2.Raised on Taiwan } \\
\text { Main Island or another } \\
\text { place }\end{array}$ & $\mathrm{N}$ & $\mathrm{N}$ & $\mathrm{N}$ & $\mathrm{N}$ & $\mathrm{N}$ & $\mathrm{N}$ \\
\hline & 1.Theme-based & & & & & & \\
\hline $\begin{array}{l}\text { Teaching } \\
\text { Model }\end{array}$ & $\begin{array}{l}\text { 2.Learning Area } \\
\text { 3.Unit Teaching }\end{array}$ & $\mathrm{N}$ & $\mathrm{N}$ & $\mathrm{N}$ & $\mathrm{N}$ & $\mathrm{N}$ & $\mathrm{N}$ \\
\hline & 4.Other & & & & & & \\
\hline Type of School & $\begin{array}{l}\text { 1.Public } \\
\text { 2.Private }\end{array}$ & $\mathrm{N}$ & $1>2$ & $\mathrm{~N}$ & $\mathrm{~N}$ & $\mathrm{~N}$ & $\mathrm{~N}$ \\
\hline
\end{tabular}

As indicated by Table 7, the results of this study were follows:

1) Subjects of different age groups exhibited significant differences in the 'adopt a child's viewpoint' dimension 
for picture book selection

Significance was observed in the 'adopt a child's viewpoint' dimension for picture book selection among teachers from different age groups. The scores of teachers $>46$ years of age were significantly higher than that of teachers aged 36-40 and $<25$ years of age. This indicates that, compared to teachers aged 36-40 and $<25$ years of age, those $>46$ years of age were better able to select suitable picture books based on their children's needs, interests, and life experiences. This result was consistent with those of Hsiao and Shen (2015) and Yu (2005), who contended that teachers of different age groups exhibited significant differences in picture book selection, and that, compared to younger teachers, older teachers were more likely to select picture books that related to children's life experiences, age, interests, and needs.

\section{2) Years of service exhibited significant differences in picture book selection}

Years of service reached significance for the 'total scale for picture book selection' and the 'theme', 'diverse characteristics and cultural implications', and 'adopting a child's viewpoint' dimensions. Subjects with 6-10 years of service exhibited a significantly higher score for the 'theme' dimension compared to those with 11-15 years of service. With regards to the 'diverse characteristics and cultural implications', 'adopting a child's viewpoint' and 'overall considerations for picture book selection' dimensions, the scores for subjects with 6-10 years of service were significantly higher compared to subjects with $<5$ years of service. This indicates that, compared to subjects with $<5$ years of experience, those with 6-10 years of service exhibited a greater acceptance of the overall factors considered in picture book selection and are, therefore, better able to comprehensively consider the determinant factors for picture book selection.

This result was consistent with that of Yu (2005), Shen (2014), Tseng (2003), and Yeh and Hsiao (2011), all of which contended that, compared to junior teachers, senior teachers exhibited a superior acceptance and consideration of the various factors in picture book selection. This conclusion is further strengthened by this study's finding that teachers with 6-10 years of service exhibited a higher score in the overall considerations required for picture book selection compared to those with $<5$ years of service. However, the present study also found that subjects with 6-10 years of service scored higher in the 'theme' dimension compared to those with 11-15 years of service. This suggests that, compared to outlying island teachers with 11-15 years of service, those with 6-10 years of service placed greater emphasis on whether the picture book content matched the course theme and teaching activities, and were more prone to select picture books based on specific topics and content.

3) The nature of the preschool exhibited a significant difference on the 'theme' dimension

The results of the present study indicate that subjects employed by public preschools scored significantly higher in the 'theme' dimension of picture book selection compared to those employed by private preschools. This indicates that, compared to private preschool teachers, public preschool teachers placed greater emphasis on whether the picture book content matched the course theme and the teaching activities, and were more prone to selecting picture books based on specific topics and content.

Nevertheless, the subjects' assigned classes, upbringing, teaching models, and level of education exhibited no significant differences for picture book selection.

5.5.2 Analyzing the Differences in Picture Book Teaching Strategies among Preschool Teachers with Different Backgrounds

An independent sample t-test and ANOVA were employed for statistical analysis. The results are presented and further discussed in Table 8: 
Table 8. Summary of the analysis results for the differences in picture book teaching strategies among teachers with different background variables

\begin{tabular}{|c|c|c|c|c|c|c|c|c|}
\hline $\begin{array}{l}\text { Background } \\
\text { Variable }\end{array}$ & Variable Attribute & $\begin{array}{l}\text { Developing } \\
\text { Diverse } \\
\text { Abilities in } \\
\text { Children }\end{array}$ & $\begin{array}{l}\text { Strategies } \\
\text { for the } \\
\text { Promotion } \\
\text { of } \\
\text { Thinking } \\
\text { and } \\
\text { Activities }\end{array}$ & $\begin{array}{l}\text { Strategies } \\
\text { for Using } \\
\text { Electronic } \\
\text { Teaching } \\
\text { Aids as } \\
\text { Auxiliary } \\
\text { Tools }\end{array}$ & $\begin{array}{l}\text { Strategies } \\
\text { for } \\
\text { Extending } \\
\text { Picture } \\
\text { Book } \\
\text { Courses }\end{array}$ & $\begin{array}{l}\text { Strategies } \\
\text { for } \\
\text { Parent-Child } \\
\text { Shared } \\
\text { Reading }\end{array}$ & $\begin{array}{l}\text { Strategies } \\
\text { for } \\
\text { Environment } \\
\text { Decoration }\end{array}$ & $\begin{array}{l}\text { Overall } \\
\text { Considerations } \\
\text { for Picture } \\
\text { Book } \\
\text { Selection }\end{array}$ \\
\hline Job Title & $\begin{array}{l}\text { 1.Teacher } \\
\text { 2.Educare-giver } \\
3 . \\
\text { Educare-Assistant }\end{array}$ & $\mathrm{N}$ & $\mathrm{N}$ & $\mathrm{N}$ & $\mathrm{N}$ & $1>3$ & $\mathrm{~N}$ & $\mathrm{~N}$ \\
\hline Age & $\begin{array}{l}\text { 1. }<25 \\
\text { 2. } 26-30 \\
\text { 3. } 31-35 \\
\text { 4. } 36-40 \\
\text { 5. } 41-45 \\
\text { 6. }>46\end{array}$ & $\mathrm{~N}$ & $\mathrm{~N}$ & $\mathrm{~N}$ & $\mathrm{~N}$ & $\mathrm{~N}$ & $\mathrm{~N}$ & $\mathrm{~N}$ \\
\hline $\begin{array}{l}\text { Education } \\
\text { Degree }\end{array}$ & $\begin{array}{l}\text { 1.High school } \\
\text { 2.College } \\
\text { 3.University } \\
\text { 4.Graduate } \\
\text { institute } \\
\text { 5.Non-related }\end{array}$ & $\mathrm{N}$ & $\mathrm{N}$ & $\mathrm{N}$ & $\mathrm{N}$ & $\begin{array}{l}3>1 \\
4>1\end{array}$ & $\mathrm{~N}$ & $\mathrm{~N}$ \\
\hline $\begin{array}{l}\text { Years of } \\
\text { Teaching }\end{array}$ & $\begin{array}{l}\text { 1. }<5 \text { years } \\
\text { 2. 6-10years } \\
\text { 3. 11-15years } \\
\text { 4. 16-20years } \\
\text { 5. }>21 \text { years }\end{array}$ & $\begin{array}{l}2>1 \\
5>1\end{array}$ & $\mathrm{~N}$ & $2>1$ & $\mathrm{~N}$ & $\mathrm{~N}$ & $\mathrm{~N}$ & $\mathrm{~N}$ \\
\hline Class & $\begin{array}{l}\text { 1.Senior Class } \\
\text { 2.Middle Class } \\
\text { 3.Junior Class } \\
\text { 4.Nursery } \\
\text { 5.Mixed-age class }\end{array}$ & $\mathrm{N}$ & $\mathrm{N}$ & $\mathrm{N}$ & $5>3$ & $5>4$ & $\mathrm{~N}$ & $\mathrm{~N}$ \\
\hline Upbringing & $\begin{array}{lr}\text { 1.Raised on } \\
\text { Outlying Islands } \\
\begin{array}{lr}\text { 2.Raised } & \text { on } \\
\text { Taiwan } & \text { Main } \\
\text { Island or } & \text { other } \\
\text { places } & \end{array}\end{array}$ & $\mathrm{N}$ & $\mathrm{N}$ & $2>1$ & $\mathrm{~N}$ & $\mathrm{~N}$ & $\mathrm{~N}$ & $\mathrm{~N}$ \\
\hline $\begin{array}{l}\text { Teaching } \\
\text { Model }\end{array}$ & $\begin{array}{l}\text { 1.Theme-based } \\
\text { 2.Learning Area } \\
\text { 3.Unit Teaching } \\
\text { 4.Other }\end{array}$ & $\mathrm{N}$ & $\mathrm{N}$ & $\mathrm{N}$ & $\mathrm{N}$ & $\begin{array}{l}1>3 \\
4>3\end{array}$ & $1>3$ & $\begin{array}{l}1>3 \\
4>3\end{array}$ \\
\hline
\end{tabular}




$\begin{array}{llllllll}\text { Type of } & \begin{array}{l}\text { 1.Public } \\ \text { 2.Private }\end{array} & \mathrm{N} & \mathrm{N} & 1>2 & 1>2 & 1>2 & \mathrm{~N} \\ \text { School } & & & & & \\ \end{array}$

Table 8 presents that the subjects' job title exhibits a significant difference regarding the 'strategies for parent-child shared reading' dimension of picture book teaching strategies. Subjects with different job titles exhibited a significant difference regarding the 'strategies for parent-child shared reading' dimension of picture book teaching strategies. The score for teachers was significantly higher than that of educare-assistants, which indicates that, compared to educare-assistants, teachers are more likely to promote parent-child shared reading and assist parents who wish to participate in this activity.

1) The subjects' level of education exhibited a significant influence on the 'parent-child shared reading' dimension of the application of picture book teaching strategies.

The results indicated that a subject's level of education reached significance in the 'strategies for parent-child shared reading' dimension of the application of picture book teaching strategies. Teachers with a university or graduate institute background in early childhood education achieved a significantly higher score compared to those with a high school/vocational school education in early childhood education. This indicates that teachers with a higher level of education were more likely to promote parent-child shared reading and assist parents to participate in this activity. Shen (2014) argued that picture books are easy to apply, and picture book teaching is a basic skill for early childhood educators. Thus, a teacher's level of education does not influence their picture book teaching behavior. Yeh and Hsiao (2011) attested that teachers with a higher level of education have a greater understanding of early childhood education and, therefore, they have a better cognition of the application of picture book teaching, yielding a significant difference. Summarizing the above, although incorporating picture books into teaching is a basic skill that all early childhood educators should possess, the professional knowledge involved in early childhood education is comprised of numerous aspects. Therefore, the author believes that all teachers have similar beliefs in and approaches to the application of picture book teaching strategies, and those differences occur in the details of these teaching strategies.

2) The subjects' years of service exhibited a significant difference with regards to the 'diverse characteristics and cultural implications' and 'strategies for using electronic teaching aids as auxiliary tools' dimensions of the application of picture book teaching strategies.

The results indicated that years of service reached significance in the 'diverse characteristics and cultural implications' and 'strategies for using electronic teaching aids as auxiliary tools' dimensions of the application of picture book teaching strategies. For 'diverse characteristics and cultural implications', subjects with $>21$ or 6-10 years of service exhibited a significantly higher score than those with $<5$ years of service. This indicates that seasoned teachers will more often apply picture book teaching so as to guide children's emotions and behavior as well as their reading observation skills. For the 'strategies for using electronic teaching aids as auxiliary tools' dimension, subjects with 6-10 years of services exhibited a significantly higher score than those with $<5$ years of service. This indicates that, compared to teachers with $<5$ years of service, those with 6-10 years of service will more often incorporate electronic teaching aids into their picture book teaching activities.

This result was consistent with that of Hsiao and Shen (2015), Yu (2005), and Tseng (2003). The majority of studies indicate that seasoned educators exhibit a superior use of picture book teaching strategies compared to junior educators. Thus, it can be inferred that seasoned educators have accumulated a greater range of teaching experience, have had more practice in applying picture book teaching strategies, and thus surpass junior teachers in certain dimensions of their teaching strategies.

3) The subjects' assigned classes exhibited significant differences in the 'strategies for extending picture book courses' and 'strategies for parent-child shared reading' dimensions of the application of picture book teaching strategies.

The results of the present study indicate that the subjects' assigned classes exhibited significant differences in the 'strategies for extending picture book courses' and 'strategies for parent-child shared reading' dimensions of the application of picture book teaching strategies. With reference to 'strategies for extending picture book courses', subjects who taught mixed-age classes exhibited a significantly higher score than those teaching junior classes. This indicates that, compared to junior classes, picture book teaching is more often incorporated into courses for mixed-age classes, and that learning is centered on after-school or outdoor activities. For 'strategies for parent-child shared reading,' subjects teaching mixed-age classes exhibited a significantly higher score than those teaching nursery classes. This indicates that, compared to teachers who taught nursery classes, those 
teaching mixed-age classes were more likely to promote parent-child shared reading and assist parents to participate in this activity. This result was consistent with Hwan and Hsiao (2008), who also observed significance in the application of picture books by teachers teaching mixed-age classes.

4) The subjects' upbringing exhibited a significant difference in relation to the 'strategies for using electronic teaching aids as auxiliary tools' dimension of the application of picture book teaching strategies

The results of the present study indicate that the subjects' upbringing is significant with regards to the 'strategies for using electronic teaching aids as auxiliary tools' in the application of picture book teaching strategies. This indicates that, compared to subjects who were raised on outlying islands, those raised on the main island of Taiwan or other regions were more likely to use electronic teaching aids as auxiliary tools in their picture book teaching activities. No major differences were found in the over application of picture book teaching strategies among teachers employed by outlying island preschools. However, this study infers that different upbringings may affect the types of teaching aids and equipment that the teachers are familiar with, which then influences the details of the application of their picture book teaching strategies.

5) The subjects' teaching models exhibited significant differences in relation to the application of their picture book teaching strategies

The results of the present study indicate that the subjects' teaching models achieved significance in relation to the total scale for picture book teaching strategy application. For the dimensions of 'overall picture book teaching strategy application' and 'parent-child shared reading' dimensions, subjects who adopted the thematic approach or combined at least two teaching methods exhibited a significantly higher score compared to those who used the unit teaching method. For the 'strategies for environment decoration' dimension, subjects who applied a thematic approach exhibited a significantly higher score than those who employed the unit teaching approach. This indicates that, compared to teachers who employed the unit teaching method, those who adopt a thematic approach or combine at least two teaching methods are more able to comprehensively apply and practice picture book teaching strategies, thereby enhancing the children's learning. A possible inference is that different teaching models have significantly different approaches and strategies and, thus, disparities occur between the application of the ideas and practices of picture book teaching.

6) The status of the preschool demonstrated a significant difference regarding the 'strategies for using electronic teaching aids as auxiliary tools', 'strategies for extending picture book courses' and 'strategies for parent-teacher shared reading' dimensions in relation to the application of picture book teaching strategies

The results of the present study indicate that the status of the preschool did not reach significance in relation to the total scale for picture book teaching strategy application. However, the status of the preschool achieved significance in 'strategies for using electronic teaching aids as auxiliary tools', 'strategies for extending picture book courses' and 'strategies for parent-teacher shared reading' dimensions, whereby the scores for public preschool teachers were significantly higher than those of private preschool teachers. This indicates that public preschool teachers are familiar with the use of electronic teaching aids as auxiliary tools in their picture book teaching, and that learning is centered on after-school and outdoor activities. Additionally, public preschool teachers were more likely to promote parent-child shared reading and assist parents to participate in this activity.

Shen (2014), Tseng (2003), and Yeh and Hsiao (2011) contested that the status of the preschool does not influence teachers' picture book teaching strategies. The findings of these studies are consistent with those of the present study in that no significant differences were observed in the overall application of picture book teaching by teachers employed by preschools of different statuses. However, differences were observed in detailed items. A possible inference is that public preschools on outlying islands are larger and have sufficient equipment, funding, and resources, which significantly affects the 'strategies for using electronic teaching aids as auxiliary tools', 'strategies for extending picture book courses' and 'strategies for parent-child shared reading'.

Nevertheless, the subjects' age exhibited no significant difference regarding the application of picture book teaching strategies

\subsubsection{Analysis on Preschool Teachers' Picture Book Selection and their Application of Teaching Strategies}

Table 3 indicates that the majority of the dimensions in the picture book selection scale and picture book teaching strategy application scale were significantly correlated, with positive correlations between 0.151 and 0.475. These correlations are considered low to moderate in general terms. This result indicates that a higher score for the picture book selection scale gives rise to a higher score for the picture book teaching strategy application scale. However, any correlations are considered relatively low in general terms. The reason may be due to the implementation of the 'Temporary Curriculum Guidelines for Preschool Childcare and Education' 
(MOE, 2013) in Taiwan. Teachers are required to integrate six major disciplines when conducting their teaching activities, and incorporate various teaching materials.

5.5.4 The Predictability of Preschool Teachers' Picture Book Selection in relation to the Application of Picture Book Teaching Strategies

Regression analysis was employed to determine whether teachers' picture book selections exhibit predictability in relation to the application of picture book teaching strategies. The details of the analysis are summarized and presented in Table 9:

Table 9. Summary of the regression analysis results on the predictability of teachers' picture book selection in their application of picture book teaching strategies

\begin{tabular}{|c|c|c|c|c|c|c|c|}
\hline Predictor & $\begin{array}{l}\text { Overall } \\
\text { Application of } \\
\text { Picture Book } \\
\text { Teaching }\end{array}$ & $\begin{array}{l}\text { Developing } \\
\text { Diverse } \\
\text { Abilities in } \\
\text { Children }\end{array}$ & $\begin{array}{l}\text { Strategies } \\
\text { for the } \\
\text { Promotion } \\
\text { of } \\
\text { Thinking } \\
\text { and } \\
\text { Activities }\end{array}$ & $\begin{array}{l}\text { Strategies } \\
\text { for Using } \\
\text { Electronic } \\
\text { Teaching } \\
\text { Aids as } \\
\text { Auxiliary } \\
\text { Tools }\end{array}$ & $\begin{array}{l}\text { Strategies } \\
\text { for } \\
\text { Extending } \\
\text { Picture } \\
\text { Book } \\
\text { Courses }\end{array}$ & $\begin{array}{l}\text { Strategies } \\
\text { for } \\
\text { Parent-Child } \\
\text { Shared } \\
\text { Reading }\end{array}$ & $\begin{array}{l}\text { Strategies } \\
\text { for } \\
\text { Environment } \\
\text { Decoration }\end{array}$ \\
\hline $\begin{array}{l}\text { Content and Style } \\
\text { Theme }\end{array}$ & $\mathrm{V}$ & & & $\mathrm{V}$ & & & $\mathrm{V}$ \\
\hline $\begin{array}{l}\text { Diverse Characteristics } \\
\text { and } \\
\text { Implications }\end{array}$ & V & V & & & V & V & \\
\hline $\begin{array}{l}\text { Adopting a child's } \\
\text { viewpoint }\end{array}$ & V & V & V & & & & \\
\hline Other & V & V & & & & & V \\
\hline
\end{tabular}

Table 9 shows that four variables for picture book selection, namely 'content and style', 'diverse characteristics and cultural implications', 'adopting a child's viewpoint' and 'other' exhibit positive predictability for 'overall picture book teaching strategies'. In addition, 'diverse characteristics and cultural implications', 'adopting a child's viewpoint' and 'other' exhibit positive predictability for 'developing diverse abilities in children' and 'adopting a child's viewpoint'. Furthermore, 'adopting a child's viewpoint' exhibits positive predictability for 'strategies for the promotion of thinking and activities'. In addition, 'content and style' exhibits positive predictability for 'strategies for using electronic teaching aids as auxiliary tools'. Moreover, 'diverse characteristics and cultural implications' exhibits positive predictability for 'strategies for extending picture book courses' and 'strategies for parent-child shared reading'. Finally, 'content and style' exhibits positive predictability for 'strategies for environment decoration'.

\section{Conclusion}

The overall status for picture book selection by early childhood educators was considered moderate to high, and the primary considerations for their picture book selections were 'adopting a child's viewpoint' and 'theme.' Differences occurred in the 'adopting a child's viewpoint' dimension for picture book selection by teachers of different age groups. Differences occurred in the overall picture book selection by teachers with different years of service. Differences occurred in the 'theme' dimension for picture book selection among teachers who taught at preschools of different statuses. The overall status for the application of picture book teaching strategies among preschool educators was considered moderate to high, with picture book teaching strategy applications focused on 'strategies for the promotion of thinking and activities' and 'developing diverse abilities in children.' Differences occurred in the 'parent-child shared reading' dimension in relation to the application of picture book teaching strategies among teachers who had different job titles. Differences occurred in the 'parent-child shared reading' dimension in regards to the application of picture book teaching strategies among teachers with different levels of education. Differences occurred in the 'developing diverse abilities in children' and 'strategies for using electronic teaching aids as auxiliary tools' dimensions with regards to the application of picture book teaching strategies among teachers with different years of service. Differences occurred in the 'strategies for extending 
picture book courses' and 'strategies for parent-child shared reading' dimensions in relation to the application of picture book teaching strategies among teachers who taught different classes. Differences occurred in the 'strategies for using electronic teaching aids as auxiliary tools' dimension with regards to the application of picture book teaching strategies among teachers with different upbringings. Differences occurred in the overall application of picture book teaching strategies among teachers with different teaching models. Differences occurred in the 'strategies for using electronic teaching aids as auxiliary tools' and 'strategies for extending picture book courses' dimensions in relation to the application of picture book teaching strategies among teachers employed by preschools of different statuses. Moreover, the presence of a correlation between picture book selection and the application of picture book teaching strategies for outlying islands preschool teachers picture book selection among outlying islands. Besides, preschool teachers exhibited predictability in relation to the application of picture book teaching strategies.

\section{Suggestions}

Preschool educators mentioned that picture book-related resources are limited in outlying islands. Aside from schools, households, and libraries in cultural centers, picture books are only accessible through specific channels. Therefore, the author suggests outlying island education offices establish education centers that provide adequate picture book resources for children. Thus, teachers on outlying islands would then be able to access sufficient picture book-related resources and apply these resources to their teaching. In addition to providing picture books at school, teachers should encourage parents to participate in parent-child shared reading schemes and organize relevant activities because picture books are suitable for all ages, enjoyable to all people, and are easy to use. Furthermore, children's language learning skills can be improved through parent-child shared reading, which in turn increases parent-child interaction and communication.

\section{References}

Chang, C. Z., \& Zheng, P. Z. (2004). Understanding picture books. Taipei: Qun-Ying.

Chen, Y. H. (2003). Create a meaningful environment for children to read and write. Guo Jiao Shi Ji, 206, 33-38.

Hong, W. Q. (1994). Promotion and application of children's books. Taipei: Chuan-Wen.

Hsiao, C. Y. (2010). Enhancing Children's Artistic and Creative Thinking and Drawing Performance through Appreciating Picture Books Activities. The International Journal of Art \& Design Education, 29(2), 143-152. http://dx.doi.org/10.1111/j.1476-8070.2010.01642.x

Hsiao, C. Y., \& Shen, M. C. (2015). Research on preschool teachers' teaching beliefs and behavior of picture book application. Journal of National Pingtung University of Education, 42, 1-36

Huang, J. C. (1993). Children's language experience. Taipei: Wu-Nan.

Ku, J. M. (2010). Children's literature and teaching. Taipei: Psychological Publishing Company.

Lewis, D. (2001). Reading contemporary picture books: Picturing text. New York: Routledge/Falmer.

Li, H. L. (2000). Combining digital media and teaching materials and methods. Instructional Technology and Media for Learning, 50, 27-41.

Lin, J. C. (2007). Principles of instruction. Taipei: Wu-Nan.

Lin, M. C. (2000). DIY Children's book club. Taipei: Tien-Wei.

Lin, M. C. (2008). A new method for children's reading. Taipei: Tien-Wei.

Lin, M. C. (2009). What are great picture books? Taipei: Tien-Wei.

Lin, M. H. (2004). Reading concert-a research on children's reading play with picture books in the classroom (Unpublished master's thesis). National Taitung University, Taitung.

Lin, M. Y. (2008). Appreciation and application of picture books. Taipei: Psychological Publishing Company.

Lin, W. B (2013). Illustrations and picture books. Taipei: National Open University Press.

Lin, Z. M. (2008). Fifteen recommended books for children: 0-3. Parenting, 2, 230.

Mayer, R. E. (2005b). Introduction to multimedia learning. In R. E. Mayer (Ed.), Cambridge Handbook of Multimedia Learning (pp. 1-16). New York: Cambridge University Press.

MOE. (2013). Temporary curriculum guidelines for preschool childcare and education. Taipei: The Ministry of Education.

Morrow, L. M. (1992). The impact of a literature-based program on literacy achievement, use of literature, and 
attitudes of children from minority backgrounds. Reading Research Quarterly, 27, 250-275.

Ning, F. T. (2004). Reading, pleasure reading: Set a bridge between teachers and students on sharing reading. Guo Jiao Shi Ji, 211, 65-72.

Pintrich, P. R. (2002). Future challenges and directions for theory and research on personal epistemology. In B. K. Hofer, \& P. R. Pintrich (Eds.), Personal epistemology: The psychology of beliefs about knowledge and knowing (pp. 389-414). Mahwah: Lawrence Erlbaum Associates Publishers.

Roskos, K., \& Neuman, S. B. (2011). The classroom environment: First, last, and always. The Reading Teacher, 65(2), 110-114.

Shen, M. C. (2014, June). Research on the use of picture book teaching beliefs and behavior for kindergarten teachers subject of use in Tainan. Poster presented at the meeting of the GCIN Conference 2014, Hong Kong.

Su, Z. M. (1998). The concepts and methods of art appreciation. 1994 Asia Regional INSEA Congress (Ed.). Proceedings of 1994 Asia Regional INSEA Congress (pp. 69-122), Taipei: INSEA.

Tseng, W. W. (2003). The research on using picture books among kindergarten teachers in Taichung City (Unpublished master's thesis). Chaoyang University of Technology, Taichung.

Wang, L. C. (2012). A study of energy-education teaching beliefs and behavior of kindergarten teachers (Unpublished master's thesis). National University of Tainan, Tainan.

Wu, Q. J. (2010). To promote reading education- encourages all Taiwan people to read. Yan Kao Shuang Yue Kan, $34(1), 62-66$.

Wu, S. L. (2005). Foreword: Picture book theme teaching resources manual. Taipei: Psychological Publishing Company.

Yeh, L. Y., \& Hsiao, C. Y. (2011). The research on selection and consumption of picture books of kindergarten teachers. Poster presented in TICE 2011 Conference, Kaohsiung, Taiwan.

Yu, S. U. (2005). The present situation of kindergarten teachers' use of picture books in Kaohsiung and Pingtung (Unpublished master's thesis). National Pingtung University of Education, Pingtung.

\section{Copyrights}

Copyright for this article is retained by the author(s), with first publication rights granted to the journal.

This is an open-access article distributed under the terms and conditions of the Creative Commons Attribution license (http://creativecommons.org/licenses/by/3.0/). 